\title{
Morphogenetic traits of the egg parasitoid Trichogramma for controlling certain date palms lepidopteran insect pests in the New Valley Governorate
}

\author{
Farouk A. Abdel-Galil ${ }^{1 *}$ (D) Sara E. Mousa ${ }^{1}$, Moustafa M. A. Rizk', Gaber H. Abo El- Hagag ${ }^{1}$ and Abd El-Latif Hesham²
}

\begin{abstract}
Egg parasitoid Trichogramma strain (TNV) received from Kharga Oasis, New Valley Governorate, Egypt, is used in controlling certain date palm lepidopteran insect pests. The morphological features of adult wasps and genetically identification of the strain was carried out. Scanning electron microscopy (SEM) and light microscope were used for studying morphology of male and female adults and measurements. Data revealed that body length of male was shorter than female. However, adult parasitoid body length of TNV was longer than the species, Trichogramma evanescens West. studied by several authors. In addition, external morphology of antennae, wings, and male genitalia were differed in TNV Trichogramma. The strain TNV identification was based on the molecular genetic techniques using PCR amplification and sequencing of the internal transcribed spacer two (ITS2) region of the rDNA. The BLAST result and phylogenetic analysis of the ITS2 region of rDNA sequence revealed that the strain TNV is closely related to Trichogramma turkestanica. Obtained results confirmed that the Trichogramma sp., used as a biological control in the New Valley, is $T$. turkestanica and not T. evanescens.
\end{abstract}

Keywords: Trichogramma turkestanica, T. evanescens, Date palm, SEM, Phylogenetic analysis, Morphological and molecular identification

\section{Background}

In Egypt, date palm (Phoenix dactylifera L.) plantations markedly increased all over the different governorates, especially in the desert new reclaimed lands (El-Assal 2004). Dates are strategic product for Egypt, which is the world's top producer of the crop, outranking Iran and Saudi Arabia. Egypt produces 1,465,030 tons of dates annually, or $17.7 \%$ of the global production of 7.5 million tons, according to the 2014 statistics of the Ministry of Agriculture and Land Reclamation (FAO 2017).

The New Valley in the western part of Egypt, from the Nile to the Libyan frontier is occupied by a vast desert plateau. In this "valley", various oases are located that are, from the North to the South: Siwa, Baharia, Farafra, Dakla, Kharga, and Fayoum. The total number of productive date palms is estimated around 700,000 trees. A large amount of them (about $50 \%)$ is grown from seeds. These date palms are very heterogeneous and, in average, of low quality. Beside the palms from seeds, mainly, one variety, "Saidi," has been propagated. It could represent nearly $50 \%$ of the total number of palms of this area. Because of its excellent quality and of the importance of its production, it was transferred to the Nile valley (Riad 1993).

Many arthropod species are known as pests of the date palm throughout the World. Around 50 species of insects and mites are reported as pests of date palms worldwide,

\footnotetext{
* Correspondence: faagalil@hotmail.com

${ }^{1}$ Plant Protection Department, Faculty of Agriculture, Assiut University, Assiut

71526, Egypt

Full list of author information is available at the end of the article
} 
from which, approximately $25 \%$ are insects and mites that considered serious pests (Haldhar et al. 2017).

The palm trees in Egypt are exposed to many insects and mites' attacks. The loss in date crops may reach about 25\%. Insect pests can attack florescence and date, leaves, roots, trunk and storage date (Alhudaib 2007).

Previously, methyl bromide was used to control insect pests in stored dates as fumigant because it was effective in killing most insect stages; but this fumigant appeared to be ozone-depleting agents (Marcotte 1993). Therefore, it was prohibited since 2005 in developing countries and by 2015 in under developed countries according to Montreal Protocol (Al-Taweel et al. 2014). Therefore, alternative safe control methods are needed. One of these methods is using biological control agents specifically the egg parasitoid, Trichogramma evanescens West. (Hymenoptera: Trichogrammatidae) in date orchards to minimize the percentage of dates infestation with lepidopteran insect pests as the Greater date moth (Arenipses sabella Hampsm), Almond moth (Cadra cautella Walk), Indian meal moth Plodia interpunctella Hub., and pomegranate fruit butterfly (Virachola livia Klug).

The Trichogrammatidae is a family of tiny wasps in the superfamily Chalcidoidea that include some of the smallest of all insects, ranging in size from 0.2 to $1.5 \mathrm{~mm}$ within the genus Trichogramma (Pinto 2006 and Ghoneim 2014). All members of this family attack eggs of insects belonging to 11 orders, e.g., Hymenoptera, Neuroptera, Diptera, Coleoptera, and Hemiptera especially Lepidoptera (Flanders and Quednau 1960 and Ghoneim 2014).

Despite the advances made in their taxonomy, Trichogramma spp. remain notoriously difficult to identify because of their tiny size and the relatively low interspecific morphological diversity (Ksentini et al. 2010). Recently, egg parasitoid Trichogramma is used for controlling the serious lepidopteran insect pests of date in the New Valley governorate.
The present work was conducted to lighten the morphological features of the adult wasps received for application in the field, with the purpose to determine the precise morphological and molecular identification of this strain.

\section{Materials and methods \\ Trichogramma collection and rearing}

Egg parasitoid Trichogramma was supplied from Trichogramma Mass Rearing Lab., Kharga Oasis, New Valley Governorate, Egypt. Eggs of Sitotroga cerealella Oliv., were used as host to produce sufficient numbers of the egg parasitoid for two generations under $\left(23 \pm 2^{\circ} \mathrm{C}, 75 \pm 5 \%\right.$ RH, L 16: D 8) at the Biological Control Lab., Plant Protection Department, Assiut University, Assiut, Northern Upper Egypt.

\section{Morphological and molecular identification of Trichogramma Morphological identification}

For light microscope Mounted Trichogramma adults on microscope slides were used as permanent specimens for species identification. Identification relies upon microscopic examination of male genitalia and other morphological characters. Dr. John Pinto, University of California at Riverside provided us with the method of Knutson (1998) for this purpose. Measurement was done using HDMI MULTI -OUTPUT HD (Toup Cam_120) CAMERA.

For scanning electron microscopy (SEM) The material was fixed in FAE (formaldehyde, acetic acid, and ethanol) and stored in $70 \%$ ethanol. Skeletal structures studied using a Jeol JSM-5400 LV scanning electron microscope following critical drying point (Hitachi HCP-2) and sputter coating of samples with gold (Giko IB-3) (Polilov 2017).
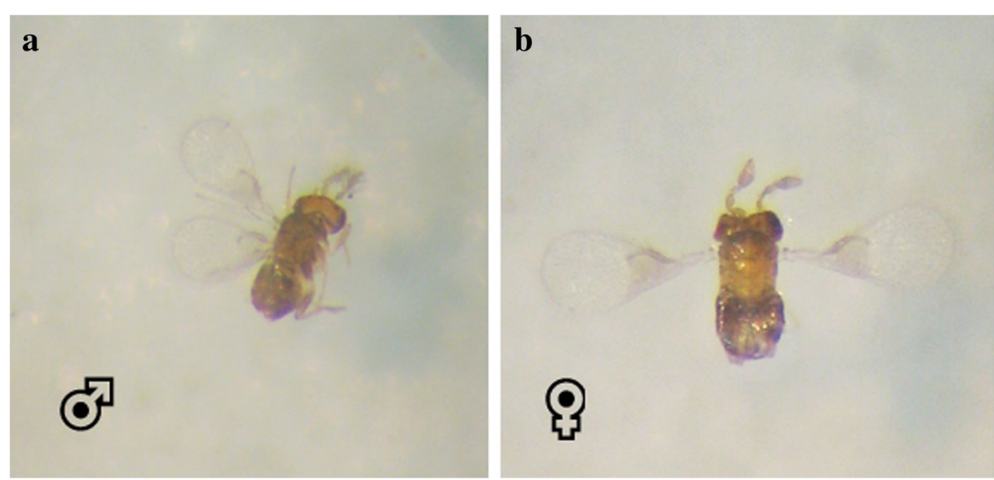

Fig. 1 a, b Male and female Trichogramma strain TNV $(x=16)$ 


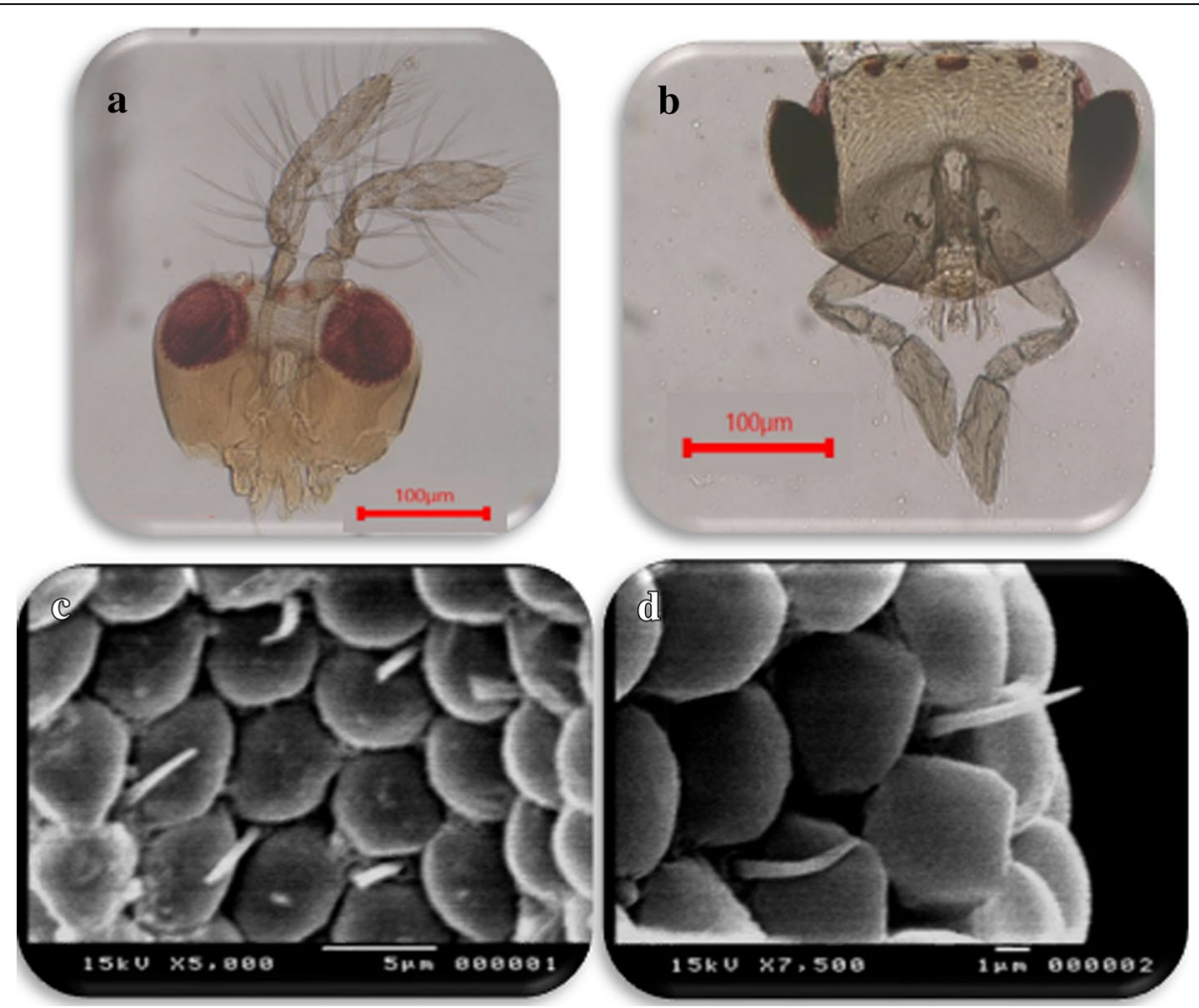

Fig. 2 The head capsule of male and female of TNV: $\mathbf{a}$, $\mathbf{b}$ light micrograph; $\mathbf{c}$, $\mathbf{d}$ SEM of male and female: interfacial hair in a corner between three facets

Measurements morphological characters The specialized terminology for the male genitalia was followed according to the modification Polaszek et al. (2012) to that of Pinto (1999). Linear measurements are reported as a mean \pm standard deviation (SD). Species were initially identified based on morphology, using a combination of the following published taxonomic accounts: Nagarkatti and Nagaraja (1971), Pintureau and Babault (1988), Pinto (1999), Pintureau (2008), and Del Pino et al. (2013).

\section{Molecular genetic identification}

Isolation of genomic DNA Total genomic DNA was extracted as described by Stouthamer et al. (1999).

PCR amplification of the Trichogramma ITS2 region of rDNA For identification, the ITS2 region of Trichogramma ribosomal DNA was amplified using the specific primers as the following: forward, 5-TGTGAACTG CAGGACACATG-3, located in the $5.8 \mathrm{~S}$ rDNA, and
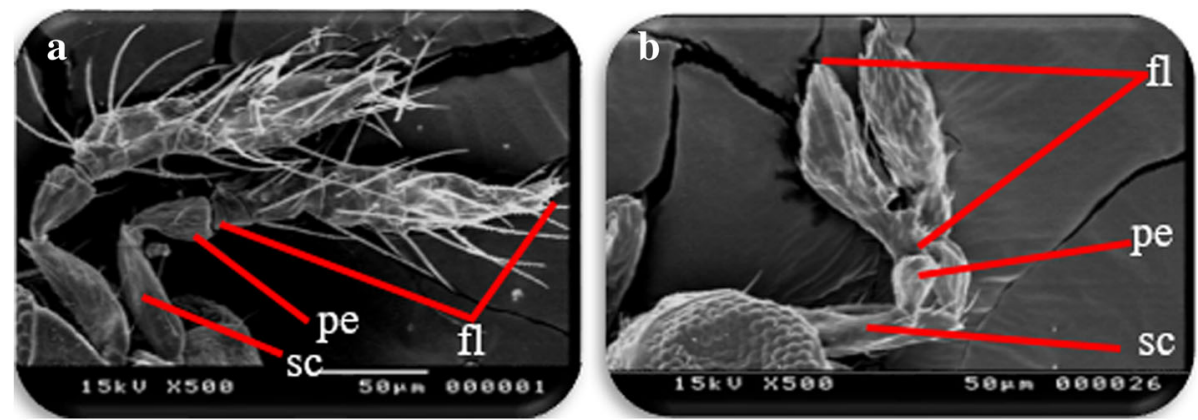

Fig. 3 The antennae of male and female of TNV: a, b SEM of male and female. fl flagellum, pe pedicel, sc scape 
Table 1 Measured characters ( $\mu \mathrm{m})$ of Trichogramma strain TNV male antenna

\begin{tabular}{|c|c|c|c|c|}
\hline \multirow{2}{*}{$\begin{array}{l}\text { Criteria } \\
(N=10)\end{array}$} & \multicolumn{4}{|c|}{ Measured characters $(\mu \mathrm{m})$} \\
\hline & $\begin{array}{l}\text { Flagellar length } \\
\text { FL }\end{array}$ & $\begin{array}{l}\text { Flagellar width } \\
\text { FW }\end{array}$ & $\begin{array}{l}\text { Scape length } \\
\mathrm{ScL}\end{array}$ & $\begin{array}{l}\text { Longest seta } \\
\text { LS }\end{array}$ \\
\hline Min. & 149.96 & 28.09 & 75.55 & 70.99 \\
\hline Max. & 171.60 & 36.83 & 96.05 & 82.76 \\
\hline Average & 162.95 & 33.11 & 82.27 & 75.63 \\
\hline$\pm \mathrm{SD}$ & 6.72 & 2.90 & 5.94 & 3.59 \\
\hline
\end{tabular}

reverse, 5-GTCTTGCCTGCTCTGAG-3, located in the $28 \mathrm{~S}$ rDNA closer to the 3 ends of the ITS2 (Stouthamer et al. 1999). The PCR reaction was performed in a final volume of $50 \mu \mathrm{L}$ containing GoTaq (Promega, Madison, WI, USA) Green Master Mix, $1 \mu \mathrm{L}$ of DNA sample, and $1 \mu \mathrm{L}$ of each primer (at a concentration of $0.5 \mathrm{mM}$ ). The PCR conditions were as follows: initial denaturation at $95{ }^{\circ} \mathrm{C}$ for $5 \mathrm{~min}$, then followed by 36 cycles at $94{ }^{\circ} \mathrm{C}$ for $1 \mathrm{~min}, 55^{\circ} \mathrm{C}$ for $1 \mathrm{~min}$, and $72{ }^{\circ} \mathrm{C}$ for $1 \mathrm{~min}$, with a final extension at $72{ }^{\circ} \mathrm{C}$ for $10 \mathrm{~min}$ and holding at $4{ }^{\circ} \mathrm{C}$.

PCR products purification and sequence determination To verify the presence of appropriate sized amplicons, the PCR product for Trichogramma strain TNV was subjected to electroph oresis using $1 \%$ agarose gel in
TAE buffer according to the standard method. Product of the correct size was purified using a TaKaRa agarose Gel DNA Purification Kit Ver.2.0 and sequenced in both directions using an $\mathrm{ABI} 3730$ automated sequencer.

Alignment and phylogenetic analysis The ITS2 sequences of Trichogramma strain TNV were aligned with known ITS2 sequences Trichogramma spp. of rDNA in the GenBank database using the basic local alignment search tool (BLAST) at the National Center for Biotechnology Information (https://blast.ncbi.nlm.nih.gov/Blast.cgi?PRO GRAM=blastn\&PAGE_TYPE=BlastSearch\&LINK_LOC= blasthome), and the percent homology scores were generated to identify the Trichogramma strain TNV.

Phylogenetic analysis The phylogenetic tree was constructed with MEGA version 4.0 using a neighbor-joining algorithm, and the Jukes-Cantor distance estimation method was performed with bootstrap analyses for 1000 replicates (Hesham et al. 2012).

GenBank accession number The partial of the ITS2 region of rDNA sequence of the strain TNV reported in this paper is deposited in the DDBJ (www.ddbj.nig.ac.jp/), EMBL (www.embl.de/), and GenBank nucleotide sequence databases (http://www.ncbi.nlm.nih.gov) under accession number MH432649.
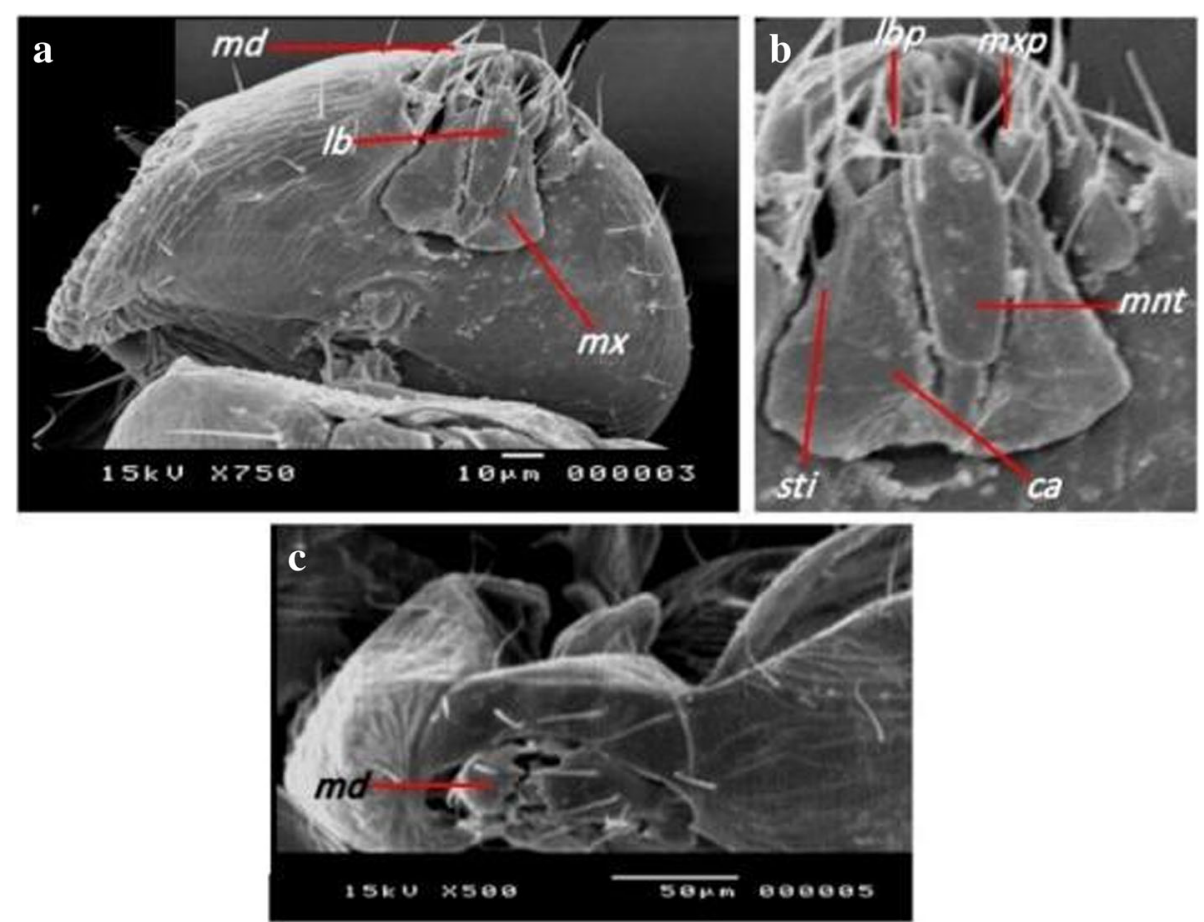

Fig. 4 The mouth parts: a, b SEM of strain TNV ventral view of head capsule with hypognathous type and chewing mouthparts. c Mandibles with undulate margin and spines on internal surface ( $m x$ maxilla, $m d$ mandible, $m \times p$ maxillary palp, lbp labial palp, ca cardo, ga galea, li ligula, mnt mentum, sti stipes) 


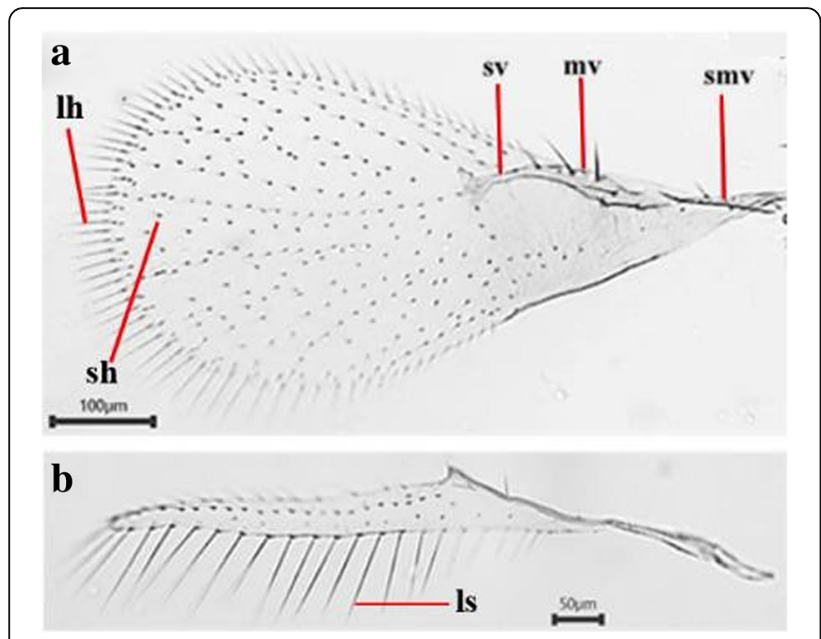

Fig. 5 Trichogramma strain TNV wings by light micrograph: a forewing (sv stigmal vein, mv marginal vein, smv submarginal vein, sh small hairs and /h longer hairs) and $\mathbf{b}$ hindwing (Is long setae)

\section{Data processing}

Measurements of morphological data were statistically analyzed by using SAS 9.12008 software program.

\section{Results and discussion \\ Morphological identification}

Using scanning electron microscopy (SEM), some morphological structures of male and female parasitoid were illustrated. By light microscopy, collected parasitoid is an extremely tiny wasp with pale yellow to brown color (Fig. 1).

\section{Body length}

Body length of adult Trichogramma strain TNV female was 472.37-608.63 $\mu \mathrm{m}$ with an average of 539.44 \pm $64.34 \mu \mathrm{m}$. However, male measurements reviled an average of $518.85 \pm 57.97 \mu \mathrm{m}$ and ranged from 456.47 to $576.84 \mu \mathrm{m}$. Thus, the male body length is shorter than female. Statistical analysis of the differences between the female and male body length are non-significant ( $T$ calculated value $=0.609421$ with $n=5$ each $)$.
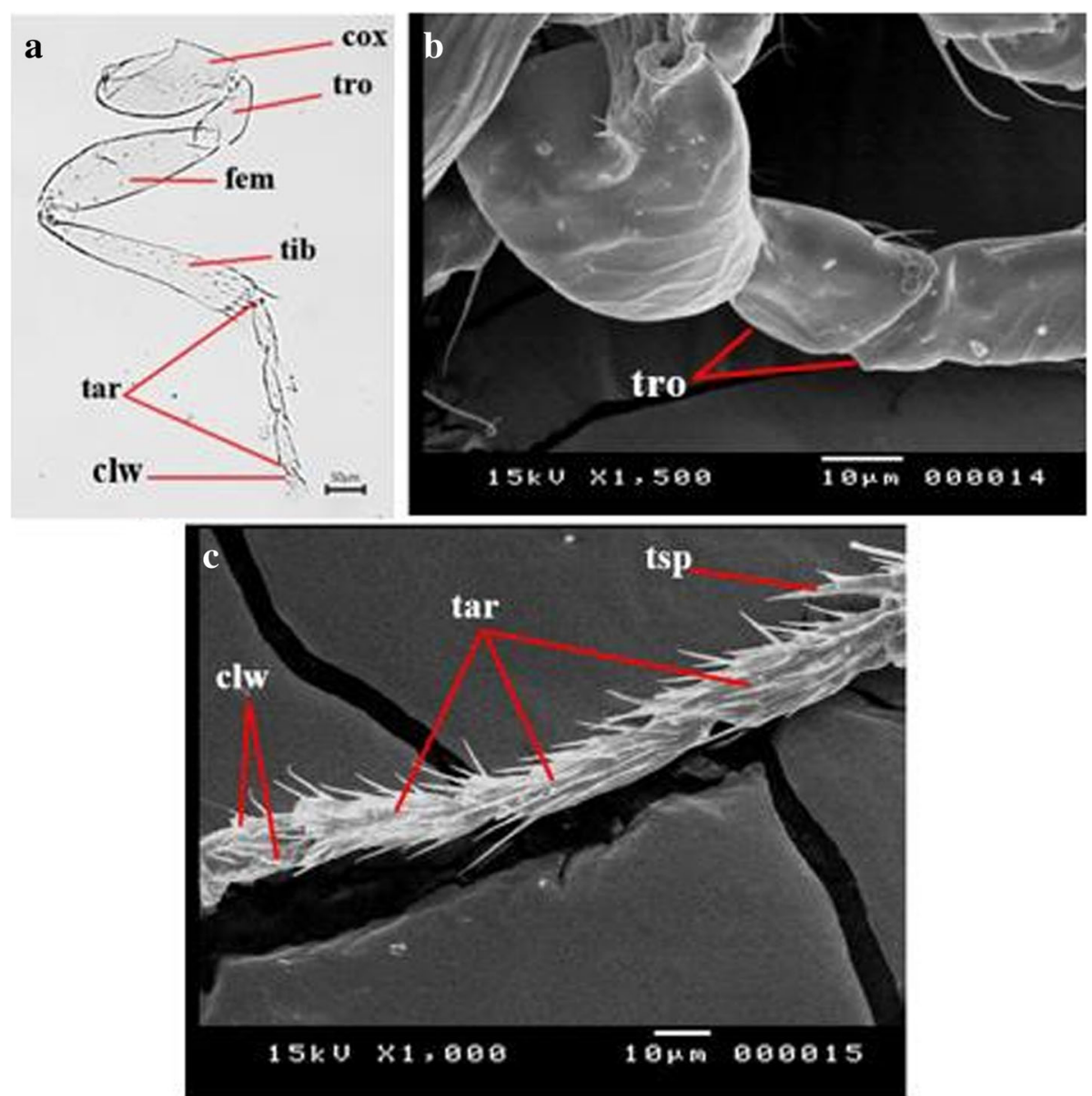

Fig. 6 a light micrograph Trichogramma strain TNV leg (cox coxa, tro trochanter, fem femur, tib tibia, tar tarsus and clw claw). b SEM tro trochanter (2 segment). c SEM tsp tibial spur, tar tarsus (3 segment) and clw claw (2 claw) 


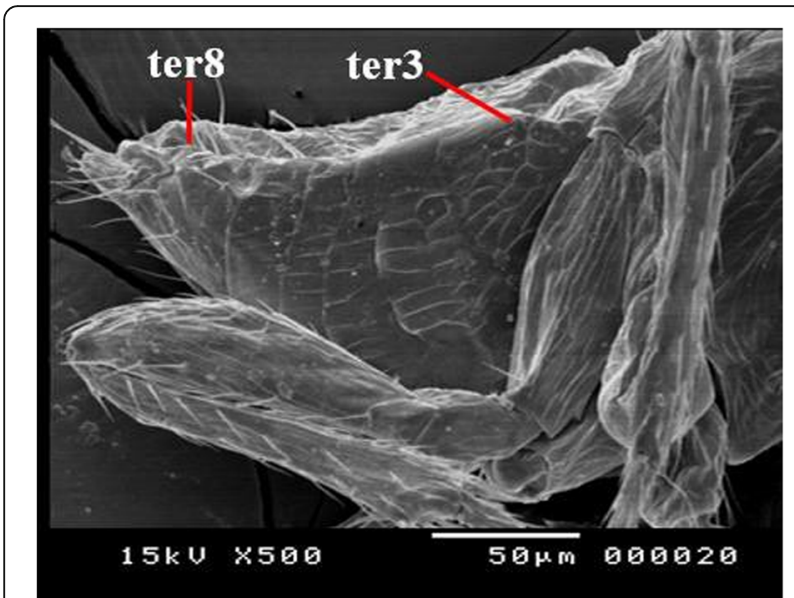

Fig. 7 SEM female abdomen metasoma lateral view (ter tergite)

\section{The head}

Compound eyes The compound eyes cover a large amount of the head (Fig. 2a). Detail of one compound eye showed interfacetal hairs distributed all across the eye (Fig. 2b). Detail of an interfacetal hair in a corner between three facets is shown (Fig. 2c).

Antennae Antenna of the strain TNV is of geniculate type, consisting of scape, pedicel, and flagellum. As shown in (Fig. 3a and b), the male hairs were more condensed and elongated than female hairs. Also, in male, segment of flagellum fused with club.

Male antennal measurements Antennal trichiation one of the morphological characters have been used to identify Trichogramma (Dang et al. 2005 and Ksentini et al. 2010). Measurements of male antennae include flagellar length (FL), flagellar width (FW), scape length (ScL), and longest seta (LS). Data presented in Table 1 based on 10 male's antennae of TNV Trichogramma strain.

Mouthparts SEM photographs of TNV indicated that the mouthparts structure is typical of chewing type. Mouthparts consist of well-developed mandibles, maxillae, and labium (Fig. 4a and b). However, labrum was weakly developed. Mandibles with undulate margin and spines on internal surface are shown (Fig. 4c). Maxillae connected with labium by membranous septum into labiomaxillary complex (Fig. 4b). Maxillae consist of cardo, stipes, fused galea and lacinia, and maxillary palp. Maxillary palp 1-segmented strongly reduced.

\section{The thorax}

Wings As shown in light micrograph for Trichogramma strain TNV, wings with strongly depleted venation (Fig. 5). Three veins preserved in forewing: submarginal, marginal, and stigmal, fused into one arch near anterior wing margin (Fig. 5a). Hindwing narrower than forewing (Fig. 5b). Forewing rather wide, covered with small hairs, with longer hairs forming fringe on perimeter of wing. Hindwing bearing fringe of long setae along posterior margin.

\section{Legs}

Legs in Trichogramma strain TNV are slender and ambulatorial. Each leg consists of coxa, 2 segmented trochanter, femur, tibia, and 3 segmented tarsi. Tibiae of legs apically bear well-developed branched spurs. Apical tarsomere bears two claws and well-developed arolium (Fig. 6a).

\section{The abdomen}

The lateral view of abdomen in TNV strain was illustrated (Fig. 7). The petiole not pronounced, mesosoma
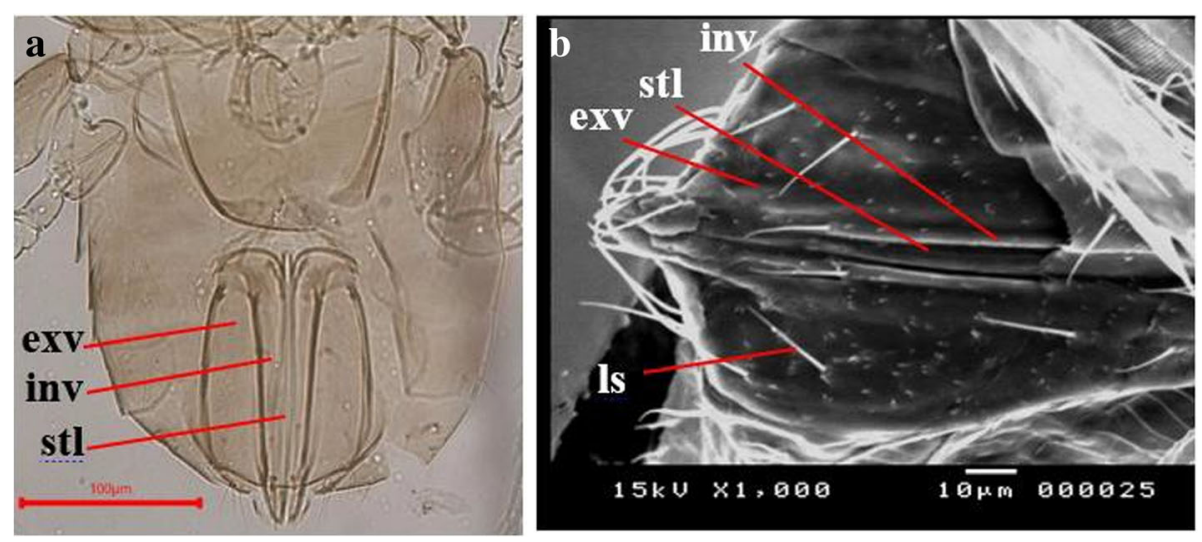

Fig. 8 Ovipositor of TNV: a light micrograph of female ovipositor ventral view. b SEM ventral view (exv external valves, inv internal valves, st/ stylet and /s long setae) 

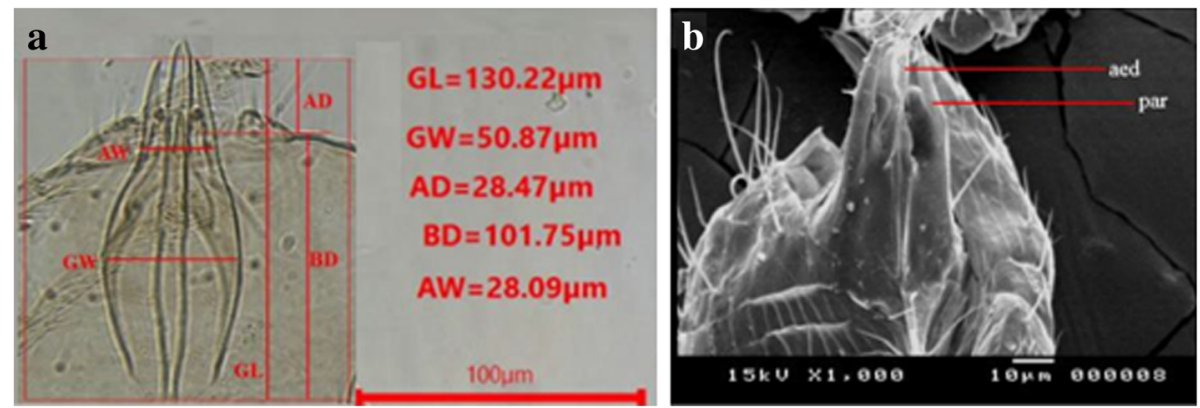

Fig. 9 Male genitalia: a light micrograph of TNV male genitalia with measurements in $\mu \mathrm{m}$ and $\mathbf{b}$ SEM of TNV male genitalia with setae and hairs

and metasoma broadly joined. Metasoma consists of six or seven visible tergites.

Measurements of female abdomen Length of female abdomen in Trichogramma strain TNV from the frons to the tip of the abdomen measured $247.086 \pm$ $10.682 \mu \mathrm{m}(231.59-258.55 \mu \mathrm{m})$. The average abdominal area reached $42,923.65 \pm 5381.776 \mu^{2} \quad(35,365.42-$ $\left.50,411.75 \mu \mathrm{m}^{2}\right)$.

Ovipositor Trichogramma strain TNV female ventral view (Fig. 8a) illustrates the ovipositor plates and stylet. SEM of TNV ovipositor showed its external and internal valves with long setae and stylet (Fig. 8b).

External male genitalia Male genitalia in strain TNV is represented by simple aedeagus, phallobase, and parameres as shown in Fig. 9a and b. Measurements of male genitalia include general length (GL), general width $(\mathrm{GW})$, apical distance (AD), basal distance (BD), and apical width (AW), which are presented in Table 2 based on 10 male genitalia of TNV Trichogramma strain.

\section{Molecular identification of Trichogramma strain TNV} using ITS-2 region of rDNA sequencing and phylogenetic analysis

To identify and determine the correct phylogenetic position of the Trichogramma strain TNV, molecular

Table 2 Measured characters $(\mu \mathrm{m})$ of TNV male genitalia

\begin{tabular}{|c|c|c|c|c|c|}
\hline \multirow{2}{*}{$\begin{array}{l}\text { Criteria } \\
(N=10)\end{array}$} & \multicolumn{5}{|c|}{ Measured characters $(\mu \mathrm{m})$} \\
\hline & $\begin{array}{l}\text { General } \\
\text { length } \\
\text { GL }\end{array}$ & $\begin{array}{l}\text { General } \\
\text { width } \\
\text { GW }\end{array}$ & $\begin{array}{l}\text { Apical } \\
\text { distance } \\
\text { AD }\end{array}$ & $\begin{array}{l}\text { Basal } \\
\text { distance } \\
\text { BD }\end{array}$ & $\begin{array}{l}\text { Apical } \\
\text { width } \\
\text { AW }\end{array}$ \\
\hline Min. & 124.9 & 44.8 & 25.44 & 85.42 & 25.44 \\
\hline Max. & 138.19 & 58.85 & 44.42 & 101.75 & 34.55 \\
\hline Average & 126.46 & 50.31 & 33.94 & 92.64 & 30.23 \\
\hline $\pm S D$ & 5.94 & 4.45 & 6.28 & 6.11 & 2.64 \\
\hline
\end{tabular}

genetic identifications were performed. As shown in (Fig. 10), the size of the amplified ITS2 region of rDNA was approximately $500 \mathrm{bp}$, which is the expected size of ITS2 region of rDNA for Trichogramma species.

The alignment and comparisons of the ITS2 sequences of rDNA of the strain TNV, to the published ITS2 sequences of rDNA in the GenBank database by BLAST search, were determined. The sequence results of the ITS2 region of rDNA of the TNV are shown to be highly homologous to Trichogramma turkestanica with $100 \%$ similarity. To confirm the position of TNV strain in the phylogeny, several sequences representing Trichogramma spp. were selected from the GenBank database to construct a phylogenetic tree. The phylogenetic analysis was performed for the TNV sequence and 10 reference sequences. As shown in Fig. 11, the phylogenetic tree indicated that TNV strain and Trichogramma turkestanica shared one clade. Therefore, the TNV strain was identified as $T$. turkestanica. Recently, molecular

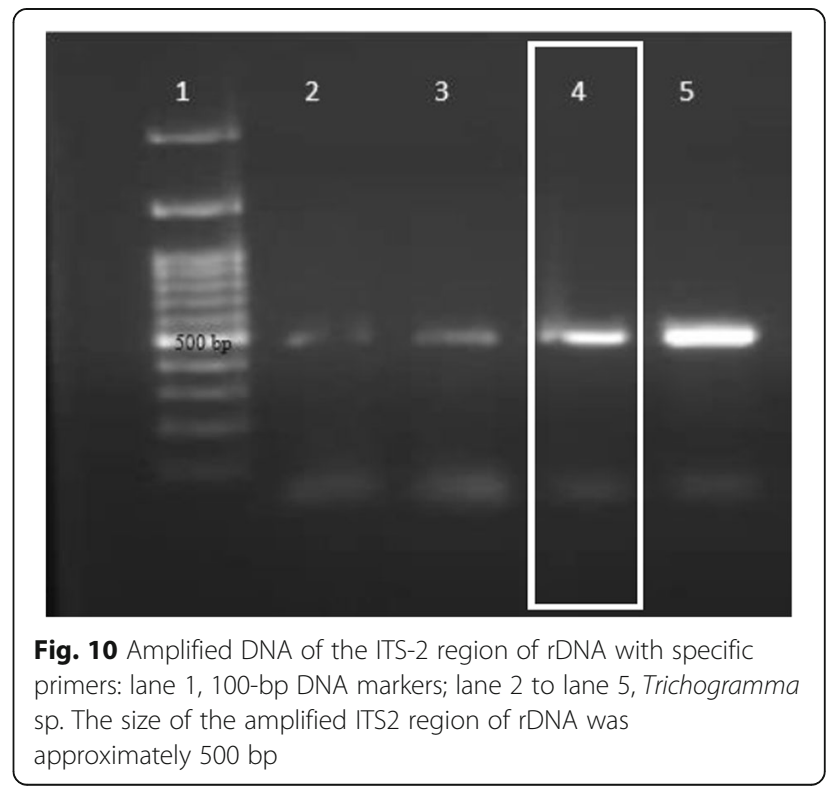




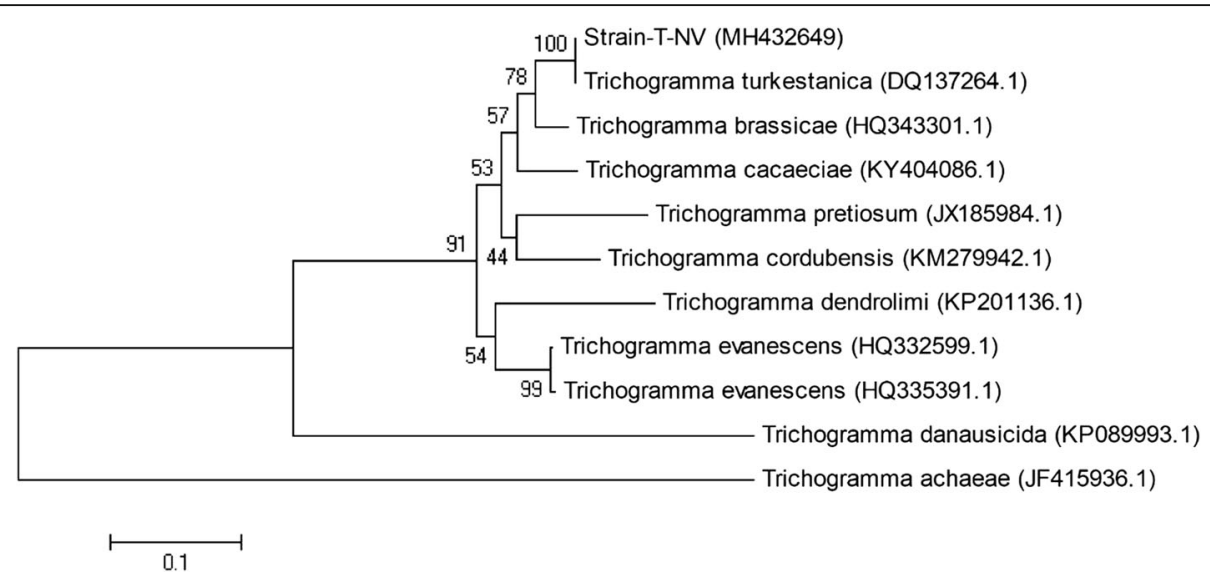

Fig. 11 Phylogenetic analysis of ITS2 region of rDNA of TNV and other related Trichogramma spp. by neighbor-joining method. In the phylogenetic tree, TNV and Trichogramma turkestanica clustered together as one clade. The scale bar indicates 0.1 nucleotide substitutions per nucleotide position. Numbers at the nodes indicate bootstrap support (\%) based on 1000 replicates. GenBank accession numbers given in parentheses

genetic tools including PCR amplification and the sequencing of the internally transcribed spacer 2 (ITS-2) of the rRNA gene were applied for the accurate identification of many Trichogramma species (Ksentini et al. 2010; Sayed et al. 2011; Polaszek et al. 2012; Pino et al. 2013; Nasir et al. 2013; Almeida and Stouthamer 2015; Wu et al. 2016 and Liu et al. 2017).

The wildly use of egg parasitoid Trichogramma encouraged biological control specialists to give extensive and intensive attention for selecting the adequate species of the parasitoid. Egg parasitoid Trichogramma (strain TNV) released in Kharga Oasis, New Valley Governorate Egypt for controlling certain date palm lepidopteran insect pests is usually recognized as Trichogramma evanescens. Results in this work discussed and supported by literature serve as good informative background. Our morphological data was compared with other author's data for T. evanescens, i.e., Fischer et al. (2011), Polaszek et al. (2012) and Polilov (2016).

Concerning body length of adult TNV female, data showed an average of $539.44 \pm 64.34 \mu \mathrm{m}$ and male measurements reviled an average of $518.85 \pm 57.97 \mu \mathrm{m}$ with an average length of both adult sex of $529.145 \pm$

Table 3 Measured characters ( $\mu \mathrm{m})$ of strain TNV and T. evanescens male antennae

\begin{tabular}{llll}
\hline Taxon & \multicolumn{3}{l}{ Measured characters $(\mu \mathrm{m})$} \\
\cline { 2 - 4 } & \multicolumn{2}{l}{ Male antennal (average \pm SD) } \\
\cline { 2 - 4 } & FL/FW & FL/SCL & LS/FW \\
\hline TNV $(n=10)$ & $4.95 \pm 0.396$ & $1.987 \pm 0.12$ & $2.299 \pm 0.22$ \\
T. evanescens & $5.6 \pm 0.1(n=4)$ & $2.1 \pm 0.1(n=3)$ & $3.1 \pm 0.2(n=4)$ \\
\hline
\end{tabular}

$58.75 \mu \mathrm{m}(n=10)$. However, the average body length of adult T. evanescens was $390 \mu \mathrm{m}(n=10)$ as mentioned by Polilov (2016).

Comparing finds of TNV male antennae with T. evanescens, results of Polaszek et al. (2012) indicated merely adequate measurements FL/FW (not including setae). In addition, as shown in Table 3, it was inadequate for FL/ ScL and LS/FW. Polaszek et al. 2012 and Polilov (2016) described the morphological features of $T$. evanescens wings. TNV differed in stigmal vein than $T$. evanescens (Fig. 12).

Several authors reported that male genitalia can be used to differentiate between egg parasitoid Trichogramma spp. (Polaszek et al. 2012 and Del Pino et al. 2013). Comparing TNV male genitalia with that of $T$. evanescens, results of Polaszek et al. (2012) indicated merely adequate measurements AW/GW. Also, as shown in Table 4, it was inadequate for GL/GW and $\mathrm{AD} / \mathrm{GL}$.

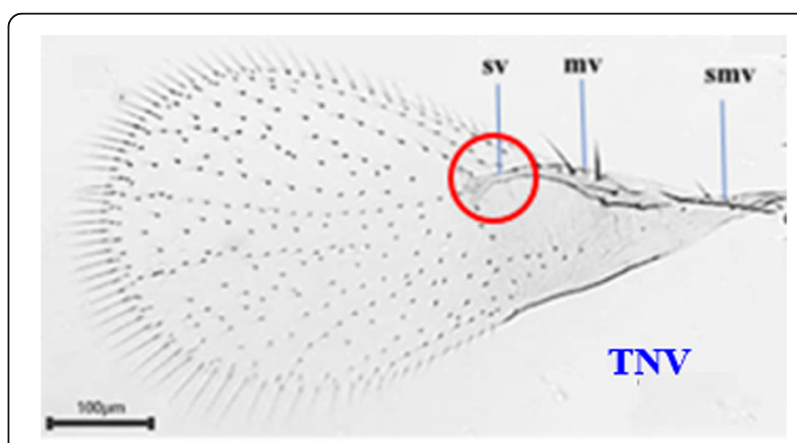

Fig. 12 Light micrograph of TNV forewing: (sv stigmal vein, mv marginal vein, and smv submarginal vein) 
Table 4 Measured characters $(\mu \mathrm{m})$ of TNV and T. evanescens male genitalia

\begin{tabular}{llll}
\hline Taxon & \multicolumn{4}{l}{ Measured characters $(\mu \mathrm{m})$} \\
\cline { 2 - 4 } & \multicolumn{3}{l}{ Male genitalia (average $\pm \mathrm{SD})$} \\
\cline { 2 - 4 } & $\mathrm{GL} / \mathrm{GW}$ & $\mathrm{AD} / \mathrm{GL}$ & $\mathrm{AW} / \mathrm{GW}$ \\
\hline TNV $(n=10)$ & $2.52 \pm 0.17$ & $0.27 \pm 0.04$ & $0.60 \pm 0.06$ \\
T. evanescens $(n=4)$ & $2.8 \pm 0.29$ & 0.3 & 0.6 \\
\hline
\end{tabular}

\section{Conclusion}

In conclusion, it is evident that the Trichogramma strain TNV was differed morphologically than $T$. evanescens, which is in use for biological control of lepidopteran date palm insect pests in the Egyptian New Valley Oasis. Also, molecular identification of the strain TNV, using ITS-2 region of rDNA and phylogenetic analysis, showed that it is highly homologous to $T$. turkestanica with $100 \%$ similarity.

\section{Acknowledgements}

We are grateful to Assiut University president and vice-president for the financial support. Also, grateful thanks for the Dean of Faculty of Agriculture for supporting in developing the Biological Control Unit at the Plant Protection Department, which was established since 2004 by F. A. Abdel-Galil.

\section{Funding}

No fund.

\section{Availability of data and materials}

Applicable.

\section{Authors' contributions}

All authors read and approved the final manuscript.

\section{Ethics approval and consent to participate}

Not applicable.

\section{Consent for publication}

Not applicable.

\section{Competing interests}

The authors declare that they have no competing interests.

\section{Publisher's Note}

Springer Nature remains neutral with regard to jurisdictional claims in published maps and institutional affiliations.

\section{Author details}

${ }^{1}$ Plant Protection Department, Faculty of Agriculture, Assiut University, Assiut 71526, Egypt. ${ }^{2}$ Genetics Department, Faculty of Agriculture, Assiut University, Assiut 71526, Egypt.

Received: 4 July 2018 Accepted: 31 October 2018

Published online: 20 November 2018

\section{References}

Alhudaib, K. A. 2007. Taxonomic list of insects attacking date palm. (http://www. redpalmweevil.com/Diseases/insleaves.htm)

Almeida RP, Stouthamer R (2015) ITS-2 sequences-based identification of Trichogramma species in South America. Braz J Biol 75(4):974-982

Al-Taweel AA, AlJboory IJ, Hameed AA, Balasem HS, Al-Gharbawi ZA, Eass AJ, Eliewi RK, Raja FA, Hussain HA (2014) Using egg parasitoid Trichogramma evanescens and pheromone traps in date palm orchards and in date warehouses to control Ephestia spp. In: Proceedings of the Fifth International Date Palm Conference, pp 321-327
Dang XL, Wen SY, He XF, Pang XF (2005) M-PCR: a powerful method for rapid molecular identification of Trichogramma wasps (Hymenoptera: Trichogrammatidae). Insect Sci 12:77-85

Del Pino M, Hernández-Suárez E, Cabello T, Rugman-Jones $P$, Stouthamer R, Polaszek A (2013) Trichogramma canariensis (Insecta: Hymenoptera: Trichogrammatidae) a parasitoid of eggs of the twin spot moth Chrysodeixis chalcites (Lepidoptera: Noctuidae) in the Canary Islands. Arthropod Syst Phylogeny 71(3):169-179

El-Assal, M. M. A. 2004. Studies on the most important pests of date palm trees in Egypt. http://www.eulc.edu.eg/eulc_v5/Libraries/Thesis/BrowseThesisPages. aspx?fn=PublicDrawThesis\&Bib|D=10812269

FAO (2017) Workshop on dates value chain development in Egypt, Cairo http:// www.fao.org/neareast/news/view/en/c/465781/

Fischer S, Mueller CH, Meyer-Rochow VB (2011) How small can small be: the compound eye of the parasitoid wasp Trichogramma evanescens (Westwood, 1833) (Hymenoptera, Hexapoda), an insect of 0.3-to 0.4-mm total body size. Vis Neurosci 28(4):295-308

Flanders S, Quednau W (1960) Taxonomy of the genus Trichogramma (Hymenoptera: Chalcidoidea, Trichogrammatidae). BioControl 5:285-294

Ghoneim K (2014) Parasitic insects and mites as potential biocontrol agents for a devastative pest of tomato, Tuta absoluta Meyrick (Lepidoptera: Gelechiidae) in the world: a review. Int J Adv Res 2:81-115

Haldhar SM, Maheshwari SK, Muralidharan CM (2017) Pest status of date palm (Phoenix dactylifera) in arid regions of India: a review. J Agric Ecol 3:1-11

Hesham A, Nadia H, Mady I, Ahmed Shoriet A (2012) 165 rRNA gene sequences analysis of Ficus elastica rubber latex degrading thermophilic Bacillus strain ASU7 isolated from Egypt. Biodegradation 23(5):717-724

Knutson A (1998) A guide to the use of Trichogramma for biological control with special reference to augmentative releases for control of bollworm and budworm in cotton. Texas Agric Ext Serv B-6071:5-98

Ksentini I, Monje JC, Jardak T, Zeghal N (2010) Naturally occurring egg parasitoids of the genus Trichogramma (Hymenoptera: Trichogrammatidae) in a pomegranate orchard in Tunisia. Entomol Sci 13(1):99-106

Liu YD, Hou ML, Song K (2017) Molecular identification of Trichogramma species from South and South-East Asia and natural Wolbachia infection. Entomol Fennica 28:57-66

Marcotte, M. 1993. United Nations Environmental Program-methyl bromide technical options committee, Food Irrad. Newsl, 17 (2): 27

Nagarkatti S, Nagaraja H (1971) Redescriptions of some known species of Trichogramma (Hym.: Trichogrammatidae), showing the importance of the male genitalia as a diagnostic character. Bull Entomol Res 61:13-31

Nasir MF, Hagedorn G, Büttner C, Reichmuth C, Schöller M (2013) Molecular identification of Trichogramma species from Pakistan, using ITS-2 region of rDNA. Biol Control 58:483-491

Pino MD, Rugman-Jones P, Herna'ndez-Sua'rez E, Polaszek A, Stouthamer R (2013) Rapid molecular identification of five species of Trichogramma occurring in the Canary Islands with notes on their distribution in banana groves. Biol Control 58:515-524

Pinto JD (1999) Systematics of the North American species of Trichogramma Westwood (Hymenoptera: Trichogrammatidae). Mem Entomol Soc Wash 22:1-287

Pinto JD (2006) A review of the new world genera of Trichogrammatidae (Hymenoptera). J Hym Res 15:38-163

Pintureau B (2008) Les espe'ces europe'ennes des trichogrammes. Libro Veritas, Cergy- Pontoise, pp 1-95

Pintureau B, Babault M (1988) Syste'matique des espe'ces africaines des genres Trichogramma Westwood et Trichogrammatoidea Girault (Hym.: Trichogrammatidae). Trichogramma and other egg parasites. In: Voegele' J, Waage J, van Lenteren JC (eds) Second international symposium, Guangzhou, China, November 10-15, 1986, pp 97-120

Polaszek A, Rugman-Jones PF, Stouthamer R, Hernandez-Suarez E, Cabello T, del Pino Pérez M (2012) Molecular and morphological diagnoses of five species of Trichogramma: biological control agents of Chrysodeixis chalcites (Lepidoptera: Noctuidae) and Tuta absoluta (Lepidoptera: Gelechiidae) in the Canary Islands. BioControl 57:21-35

Polilov AA (2016) At the size limit-effects of miniaturization in insects. Springer International Publishing, Switzerland. https://doi.org/10.1007/978-3-319$39499-2 \_8$

Polilov AA (2017) Anatomy of adult Megaphragma (Hymenoptera: Trichogrammatidae), one of the smallest insects and new insight into insect miniaturization. PLoS One 12(5):e0175566. https://doi.org/10.1371/journal. pone.0175566 
Riad M (1993) The date palm sector in Egypt. In: Ferry M. (ed.), Greiner D. (ed.). Le palmier dattier dans l'agriculture d'oasis des pays méditerranéens. Zaragoza: CIHEAM, 1993. p. $45-53$ (Options Méditerranéennes: Série A. Séminaires Méditerranéens; n. 28) http://om.ciheam.org/article.php?IDPDF=96605879

Sayed SM, El-Shehawi AM, Al-Otaibi SA (2011) Molecular and biological characterization of Trichogramma turkestanica (Hymenoptera:

Trichogrammatidae) which inhabits Taif governorate at the west of Saudi Arabia. Afr J Biotechnol 10(46):9467-9472

Stouthamer R, Hu J, Van Kan FJ, Platner GR, Pinto JD (1999) The utility of internally transcribed spacer 2 DNA sequences of the nuclear ribosomal gene for distinguishing sibling species of Trichogramma. BioControl 43:421-440

Wu LH, Hoffmann AA, Thomson $\sqcup$ (2016) Taiwanese Trichogramma of Asian corn borer: morphology, ITS-2 rDNA characterization, and natural Wolbachia infection. J Insect Sci 16(1):1-7. https://doi.org/10.1093/jisesa/iew006

\section{Submit your manuscript to a SpringerOpen ${ }^{\circ}$ journal and benefit from:}

- Convenient online submission

Rigorous peer review

- Open access: articles freely available online

High visibility within the field

- Retaining the copyright to your article

Submit your next manuscript at $\boldsymbol{\nabla}$ springeropen.com 